\title{
CORRELATION STUDY OF ZOOPLANKTON DIVERSITY, SPECIES RICHNESS AND PHYSICO-CHEMICAL PARAMETERS OF GHODAZARI LAKE (MAHARASHTRA)
}

\author{
A. V. Dorlikar \\ P.G. Department of Zoology and Research Academy, Sevadal College for Women, Nagpur-440024, India \\ ajaydorlikar@gmail.com
}

\begin{abstract}
Zooplankton diversity and species richness can be affected by physico-chemical characteristics, morphology of lake and human activity in the catchment area of the lake. Zooplankton diversity and the physicochemical characteristics of the lake is an important criterion for evaluating the trophic status of the lake and suitability of water for domestic purposes. Thus study was undertaken to evaluate the zooplankton community structure diversity, seasonal variation in the population and its correlation with physico-chemical parame ters in Ghodazari Lake. The present study was undertaken for a period of 6 months from January 2016 to June 2016. Water samples were collected on monthly basis from selected sampling site for analyzing the physic-chemical parameters and population dynamics of the zooplanktons in the reservoir. A total of 26 zooplankton taxa were recorded: 11 rotifers, 5 copepods, 7 cladoce rans and 3 os tracods. Zooplanktons were present in the following order of dominance; Rotife ra > Cladocera > Cope poda > Ostracoda. The physico-chemical parameters considered in the present study we re: wate $\mathrm{r}$ temperature, $\mathrm{pH}$, trans parency, e lectrical conductivity, diss olved oxygen, total hardness, biological oxygen demand and chemical oxygen demand. Correlation coefficients (R) were determined using correlation matrix to identify the correlation between zooplankton diversity and physico-che mical parameters. Shanon-Weiner Index was in the range of 4.51 to 4.61 indicating lake preserves rich plankton diversity. Presence of pollution tole rant taxa like Brachionus, Keratella and Lecane spp. indicate semipolluted water of the reservoir. The trophic status of the lake evaluated from the zooplankton analysis and physico-chemical parameters indicates that the lake is mesotrophic nature.
\end{abstract}

Keywords : zooplankton dive rsity, Ghodazari Lake, rotifera, correlation matrix, phys ico-chemical parameters

\section{Introduction}

Ghodazari lake is a freshwater natural lake situated at $20^{\circ} 32^{\prime} 29.25^{\prime \prime} \mathrm{N}$ longitude, $79^{\circ}$ 37 ' 44.33" E latitude at the elevation of $245 \mathrm{Mts}$. in Chandrapur district, Maharashtra. This Lake serves as a source of domestic water for near about villages. It is the refore very important to keep the quality of water good for domestic purposes. Zooplanktons plays important role in food web by linking the primary producers with consumers of higher trophic levels of the lake ecosystem. Many species of the zooplanktons have high potentiality as a bioindicator to monitor quality of water and their density can be correlated with biotic and abiotic factors of the water bodies (Ferdous and Muktadir, 2009). Zooplanktons are sensitive to the changes in environmental conditions, thus are good indicators of changes in water quality parameters (Schindler, 1987). Thus present investigation is an attempt to assess the water quality parame ters, zooplankton community structure, dominance, abund ance and density in Ghodazari Lake.

\section{Materials and Methods}

Sample collection was carried out monthly from January 2016 to June 2016. Zooplankton samples were collected by filtering 50 liters of the lake water through standard plankton nylon net with me sh size $55 \mu \mathrm{m}$.
The concentrated samples were preserved in $4 \%$ formalin soon after the collection. Identification was carried out by using stand ard lite rature. The recorded species were identified following Ward and Whipple, 1959; Edmondson, 1959; Mizuno, 1964; Dussart,1969; Harding and Smith,1974; Kolisko,1974; Koste ,1978; Victor and Fernando, 1979; Mizuno and Takahashi 1991; Battish ,1992; Reddy,1994; Michel and Sharma,1998 and Dhanapathi,2003. Quantitative analysis and evaluations were carried out according to Edmondson (1959) and Telesh (1986).

Six indices were used to estimate zooplankton diversity and species richness. Species diversity index was calculated based on Simpson (1949) and Shannon-Weiner (1949); richness index was adopted by Margalef (1951) and Menhinic (1964) and equitability Index by Magurran(1988). Dominance index or Simpson's index of dive rsity was calculated using formula 1Simpson index. The percentage relative abundance of the specimens was estimated by direct count.

The collection and analysis of various physic-chemical parameters of water samples were carried out by following the standard methods (APHA, 2005; Saxena, 1994; Manivasakam, 1982; Trivedy and Goel, 1986). Triplicates of each analysis were performed and mean values were used for calculation. 


\section{Statistical Analys is}

The correlation coefficient matrix between each pair of parame ters was estimated to identify the highly correlated and interrelated water quality parameters. Statistical analysis was carried out using Statistical Package for Social Sciences (SPSS 10.0).

\section{Results and Discussion}

Lakes are important wetlands which plays their role as a source of water for drinking and domestic purposes. Lakes improves the water table of the near about areas and forms its own ecosystem and supports flora and fauna of that region. However exponential growth of the population and urbanization has created tremendous pressure on the lakes thereby leading to the problems like eutrophication and influencing the trophic status of the lakes. Thus regular assessment of water quality parameters and zooplank ton diversity is essential to evaluate the trophic status of the lake.

In present investigation 11 species of Rotifera including 2 families and 5 genera, 7 species of cladocera including 5 families and 6 genera, 5 species of Copepoda including 3 families and 5 genera and 3 species belonging to Ostracoda were noted. Overall 26 species of zooplankton were reported (Table 1). The most abundant taxonomic group recorded during the study was the rotifers. Zooplankton we re present in the following order of dominance; Cladocera > Rotifera $>$ Copepoda $>$ Ostracoda. The community structure of zooplankton showed a mixed composition of mesotropic to eutropic species. Brachionus species are indicator of eutropic conditions (Baloch and Soomro, 2004). Presence of pollution tolerant taxa like Brachionus, Keratella and Lecane spp. indicate semipolluted waters of the reservoir (Patrick, 1950). Abundance of mesotropic species like Keratella vulga, Keratella tropica indicates the mesotropic nature of the reservoir. $M$. micrura and Diaphanosoma and Alona were the main dominant cladocerans in Ghodazari reservoir, while other species remain rare. The cladoceran populations are rich in density but poor in species diversity.

Zooplankton density and relative abundance is shown in graph. (Fig.1 and Fig. 2).

Composition of zooplankton community

is strongly dependant on the season. In the current study the density of rotifers was maximum during winter in February (31.08\%) and minimum at the summer in May (20.21\%). Cladoce ran density was maximum during winter $(45.83 \%)$ and minimum during the premansoon in June (31.63\%). Copepods showed their maximum density during summer (26.95\%) and minimum density (16.66\%) during winter. However ostracods showed their maximum density during summer (14.90\%) and minimum density du ring winter (7.5\%).

The values for biodiversity ind ices that is Simpson index, Dominance index, Shannonweiner index, Menhinik index and Equalitability index are represented in the Table. 2. Shannonweiner index values are in the range of 4.51 to 4.61 and Margalef richness index values are in the range of 4.25 to 4.62 confirms the meso tropic status of this reservoir. Simpson index values as low as 0.040 and maximum 0.045 while Dominance index is high as 0.95 are good indicators of rich diversity of species in this reservoir. From the equitability index (0.95 to 0.98 ) it is evident that dis tribution of zooplankton species during the study was eve $n$ and fallows the Lorenz graph. Evenness, is therefore, best used as a baseline value to which future studies can be compared. No major fluctuation was found in the equitability index during entire study period.

\section{Physico-chemical parameters of water}

The physico-chemical parameters of water at Ghodazari lake is represented in the Table 3.

\section{Water temperature}

Temperature of Reservoir water ranged from $19.4^{\circ} \mathrm{C}$ to $30.3^{\circ} \mathrm{C}$ during entire study period. Seasonal fluctuations were observed during the inves tigation.

\section{pH}

During present study water $\mathrm{pH}$ values were ranged from 7.6 to 8.4. Alkaline nature of the reservoir was noted during the entire investigation period. $\mathrm{pH}$ range of 7.5 to 8.5 is desirable concentration as per guide lines of WHO (2004). pH range from 5 to 8.5 is best for plankton growth (Umavathi et al., 2007).

\section{Transparency}

In the present investigation transparency was ranged from $19.0 \mathrm{~cm}$ to $30.2 \mathrm{~cm}$.

Higher trans parency occurred, during win ter and summer due to less suspended particles and absence of influx of slit.

\section{Electrical cond uctivity}

Present investigation revealed that, conductivity fluctuated between $300 \mu \mathrm{mho} / \mathrm{cm}$ to 614 $\mu \mathrm{mhos} / \mathrm{cm}$. Total amount of ionisable salts in water were positively correlated with electrical conductivity (Bobori, 1996).

\section{Dissolved oxygen}

In the present investigation the dissolved oxygen was in the range of $5.0 \mathrm{mg} / \mathrm{L}$ to $8.0 \mathrm{mg} / \mathrm{L}$. Dissolved oxygen concentration more than $5 \mathrm{mg} / \mathrm{L}$ favors good growth of flora and fauna. 


\section{Total Hardness}

In the pre sent investigation to tal hardness was in the range of 110 to $177 \mathrm{mg} / \mathrm{L}$. Many workers has noted a positive correlation between temperature and hardness (Jhingran, 1982; Singh, 1986). The observed values of hardness are in the permissible limit of drinking water (WHO, 2004). Biological Oxygen Demand (BOD) and Chemical Oxygen Demand (COD)

During present investigation minimum BOD and COD values ranged from 2.1 to $4.0 \mathrm{mg} / \mathrm{L}$ and 8.0 to $12.4 \mathrm{mg} / \mathrm{L}$ respectively. Significant correlation $(r=0.9)$ in between BOD and COD was observed during the investigation.

Correlation among the Physico-chemical parameters and Zooplanktons:

Correlation matrix of the physico-chemical variables is shown in Table 4.

A positive correlation be tween wate $\mathrm{r}$ temperature and $\mathrm{pH}$, hardness, BOD, COD, copepoda and plankton density was observed in the present study. However negative correlation exists with cladocera (Table.4).

The $\mathrm{pH}$ of the Ghodazari rese rvoir water showed significant positive relationship with hardness, BOD and COD. However inverse relationship was noted with transparency and cladocera.

In the prese nt investigation transparency showed ne gative correlation with dis solved oxyge $n$.

Conductivity showed a positive correlation with hardness, BOD and ostracoda and negative relationship with DO.
Dis solved oxygen (DO) showed a significant correlation with COD.

Hardness in the present study showed significant positive relationship with $\mathrm{BOD}, \mathrm{COD}$, copepoda and density of zooplankton and negative significant corre lation with cladocera.

BOD and COD showed positive significant correlation with copepoda and zooplankton density and significant negative correlation with cladocera.

Among zooplanktons rotife ra population showed significant positive correlation with dissolved oxygen. Cladocera showed negative significant correlation with temp, $\mathrm{pH}$, hardness, BOD and COD. Copepoda showed significant positive correlation with temp, hardness and BOD. However Ostracoda showed significant positive correlation with conductivity.

Zooplankton density showed positive correlation with te $\mathrm{mp}, \mathrm{pH}$, hardness and BOD.

\section{Conclusion}

The results obtained from the present investigation revealed that, all values the physical and chemical properties of Ghodazari reservoir water we re within desirable limits as per the guidelines of the WHO (2004). Thus water of Ghodazari reservoir is suitable for irrigation, pisiculture and drinking purpose.

Table 1: Zooplankto n species ide ntified in Ghodazari Reservoir

\begin{tabular}{llll}
\hline Rotifera & Cladocera & Cope poda & Ostracoda \\
\hline Family: Brachionidae & Family: Sididae & Family: Diaptomidae & Cypris subglobosa \\
Brachionus bidentata & Diphanosoma & Diaptomus & Stenocypris \\
B. falcatus & Family:Daphnidae & Heliodiaptomus viddus & Eucypris \\
B. ureceolaris & Ceriodaphnia reticulata & Family: Cyclopidae & \\
B. forficula & Family: Moinidae & Cyclopsleuckartï & \\
B.calyciflorus & Moina micrura & Mesocyclops hyalinus & \\
B.quadidentatus & Family: Bos minidae & Family:Canthoca mptidae & \\
Keratella tropica(Apstein) & Bosmina longirostris & Nauplï & \\
Keratella vulga & Bosmina coregoni & & \\
Lecane arculata & Family: Chydoridae & & \\
Filinia longiseta & Chydorus globosus & & \\
Family: Asplanchnidae & Alona rectangula & & \\
Asplanchnaa priodonta & & & \\
\hline
\end{tabular}

Table 2 : Zooplankton community structure and a-biodiversity indices of Ghodazari reservoir.

\begin{tabular}{lllllll}
\hline Month & $\begin{array}{l}\text { Simpson } \\
\text { Index }\end{array}$ & $\begin{array}{l}\text { Dominance } \\
\text { index }\end{array}$ & $\begin{array}{l}\text { Shanon-Weiner } \\
\text { index }\end{array}$ & $\begin{array}{l}\text { Margalef } \\
\text { Richness } \\
\text { index }\end{array}$ & Menhinic index & $\begin{array}{l}\text { Equitability } \\
\text { Index }\end{array}$ \\
\hline Jan & 0.044 & 0.95 & 4.51 & 4.56 & 1.67 & 0.96 \\
Feb & 0.041 & 0.95 & 4.57 & 4.62 & 1.74 & 0.97 \\
Mar & 0.043 & 0.95 & 4.55 & 4.40 & 1.52 & 0.96 \\
Apr & 0.043 & 0.95 & 4.55 & 4.37 & 1.49 & 0.96 \\
May & 0.045 & 0.95 & 4.49 & 4.43 & 1.54 & 0.95 \\
Jun & 0.040 & 0.95 & 4.61 & 4.25 & 1.38 & 0.98 \\
\hline
\end{tabular}


Table 3. Range of variation, Mean \pm standard error of the physico-chemical characteristics of wate $r$ of Ghodazari lake during January, 2016 to June, 2016

\begin{tabular}{llllll}
\hline S. No. & Parameter & Unit & \multicolumn{2}{c}{ Range of Variation } & Mean \pm Std. Error \\
\cline { 3 - 4 } & & & Min & Max & \\
\hline 1. & pH & -- & 7.6 & 8.4 & $7.72 \pm 0.4$ \\
2. & Water Temp. & ${ }^{0} \mathrm{C}$ & 19.4 & 30.3 & $23.9 \pm 1.66$ \\
3. & Transparency & $\mathrm{Cm}$. & 19.0 & 30.2 & $26.6 \pm 1.07$ \\
4. & Electrical Conductivity & $\mu \mathrm{mho} \mathrm{Cm}^{-1}$ & 300 & 614 & $477 \pm 47.4$ \\
5. & Dissolved Oxygen & $\mathrm{mgL}^{-1}$ & 5.0 & 8.0 & $6.6 \pm 0.52$ \\
6. & Total Hardness & $\mathrm{mgL}^{-1}$ & 110 & 177 & $143.83 \pm 10.4$ \\
7. & B.O.D. & $\mathrm{mgL}^{-1}$ & 2.1 & 4.0 & $2.56 \pm 0.31$ \\
8. & C.O.D. & $\mathrm{mgL}^{-1}$ & 8.9 & 12.4 & $10.08 \pm 0.53$ \\
\hline
\end{tabular}

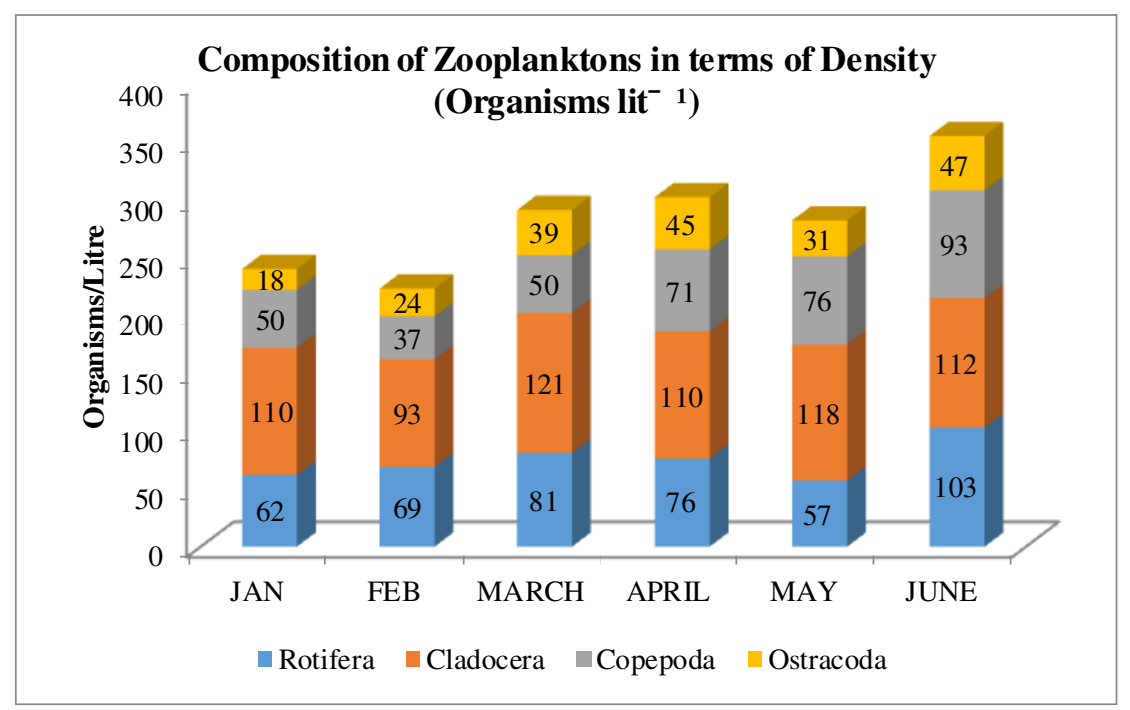

Fig,1. Composition of Zooplanktons in terms of de nsity.

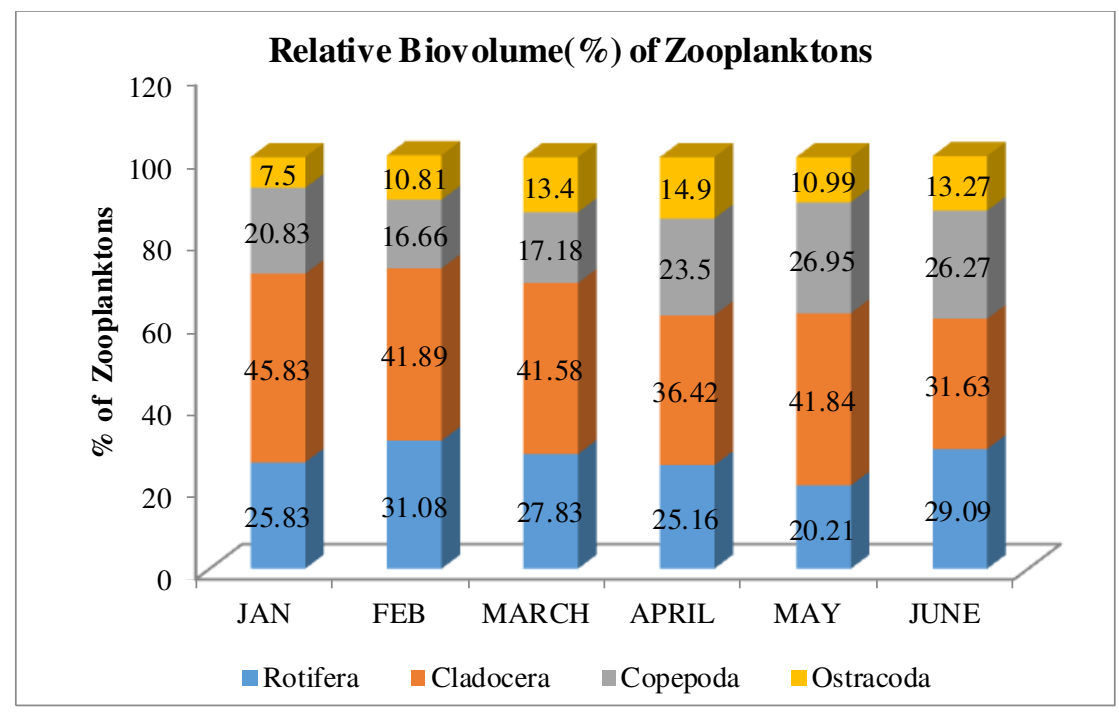

Fig, 2. Re lative biovolume (\%) of Zooplank tons 
Table 4. Correlation matrix of the physico-chemical variables of Ghodazari rese rvoir . (method = Pearson)

\begin{tabular}{|c|c|c|c|c|c|c|c|c|c|c|c|c|c|}
\hline $\mathrm{r}$ & Temp & $\mathrm{pH}$ & Trans & Cond & DO & Hardness & BOD & COD & Rotife ra & Cladocera & Cope poda & Ostracoda & Density of Org. \\
\hline Temp & 1 & & & & & & & & & & & & \\
\hline $\mathrm{pH}$ & 0.905 & 1 & & & & & & & & & & & \\
\hline Transparency & -0.498 & -0.728 & 1 & & & & & & & & & & \\
\hline Conductivity & 0.626 & 0.343 & 0.335 & 1 & & & & & & & & & \\
\hline $\mathrm{DO}$ & -0.099 & 0.272 & -0.723 & -0.733 & 1 & & & & & & & & \\
\hline Hardness & 0.963 & 0.814 & -0.306 & 0.793 & -0.283 & 1 & & & & & & & \\
\hline BOD & 0.915 & 0.753 & -0.423 & 0.655 & -0.258 & 0.937 & 1 & & & & & & \\
\hline COD & 0.873 & 0.888 & -0.625 & 0.48 & 0.087 & 0.873 & 0.902 & 1 & & & & & \\
\hline Rotifera & -0.209 & 0.172 & -0.419 & -0.484 & 0.821 & -0.255 & -0.306 & 0.125 & 1 & & & & \\
\hline Cladocera & -0.826 & -0.867 & 0.523 & -0.539 & -0.078 & -0.859 & -0.828 & -0.975 & -0.228 & 1 & & & \\
\hline Cope poda & 0.805 & 0.614 & -0.287 & 0.566 & -0.428 & 0.774 & 0.834 & 0.62 & -0.624 & -0.509 & 1 & & \\
\hline Ostracoda & 0.527 & 0.406 & 0.06 & 0.754 & -0.263 & 0.7 & 0.6 & 0.651 & 0.105 & -0.748 & 0.164 & 1 & \\
\hline Density of Org. & 0.882 & 0.771 & -0.53 & 0.544 & -0.039 & 0.891 & 0.948 & 0.925 & -0.085 & -0.863 & 0.638 & 0.685 & 1 \\
\hline
\end{tabular}

*The values $(r)$ ranging from 0.576 and above, 0.708 and above are significant at $P \leq 0.05(2$-tailed) and $P \leq 0.01(2$-tailed), respectively. 


\section{References:}

APHA (2005) Standard methods for the examination of water and waste water. 21st edition; American public health Association, American water works association, Wate r environment federation, Washington DC, USA.

Baloch, W.A. and Soomro, A.N. (2004) Rotifers of the adjacent areas of Hyderabad, Sindh. Pakistan Journal of Zooloogy. 36 (4): 319-322.

Bobori, D. (1996) Bioaccumulation of heavy metals in the ecosystem of lake Koronia (Macedonia, Greece). Bios., 4: 171-174.

Dhanapathi, M.V.S.S.S. (2003) Rotifers from Andhra Pradesh, India- III. Hydrobiologia. 48(1): 9-16.

Dussart, B.(1969) Les Copepodes des eaux continentales,2.Cyclopoides et Bio-logie: N. Boubee (ed.) Paris, 292pp.

Edmundson, W. T. (ed). (1959) Fresh-water biology (2nd ed.). John Wiley and Sons, New YorkNew York,, 1248 pp.

Ferdous, $Z$ and Muktadir, A.K.M. (2009) A Review: Potentiality of Zooplankton as Bioindicator. American journal of Applied Sciences, 6 (10):1815-1819.

Harding, J.P. and Smith, W.A. (1974) A key to the British freshwater cyclopoid and calanoid copepods. Scientific Publications of the Freshwater Biological Association, No. 18.

Jhingran, V.C. (1982) Fish and fisheries of India. Hindustan Publishing Corporation, Delhi, India.

Kolisko, R.A. (1974) Plankton Rotifers Biology and Taxonomy. Die Binnengewasser. Volume XXVI / I. Supple ment, Stuttagart. 146pp.

Koste, R.A. (1978) Die Radertiere Mitteleuropas I. Textband. Berlin, Stuttgart, 670pp.

Magurran, A.E. (1988) Ecological Diversity and Its Measurement. Princeton University Press, Princeton, New Jersey.

Manivasakam. N. (1982) Industrial Effluents.Origin, characteristics, effects, analysis and treatment. 4th Edition, Sakthi publications, Coimbatore, 267-333.

Margalef, D.R. (1951) Diversidad de especies en les communideades natural Public Institutte of Biologic, Barcelonia 9: 5- 27.

Me nhinick E.P. (1964) A comparis on of some speciesindividuals diversity indices applied to samples of field insects. Ecology. 45. 859-861.
Michael , R.G. and Sharma, B.K. (1998) Fauna of India and adjacent countries. Indian cladocera (crustacea: Branchipoda: Cladocera). Zoological Survey of India. $262 \mathrm{pp}$.

Mizuno, T. (1964) Illustrations of freshwater plankton of Japan. Hoikusha.351 pp.

Mizuno, T. and Takahashi, E. (1991) An illustrated guide to Freshwater Zooplankton in Japan. Tokai Unive rsity Press.

Patrick, R. (1950) Biological measure of stream conditions. Sewage and Industrial Wastes , 22(7):92693

Reddy, Y.R. (1994) Copepoda: Calanoda: Diaptomidae: Guide to the identification of the microinverte brates of the continental waters of the world. Vol.5 SPB Publishers, The Hague, Netherland.

Saxena, M.M. (1994) Environmental Analysis - water, soil and air. Agro Botanical Publishers (India), 2nd Edition, 4-86: 121-125

Schindler, D. W. (1987) Detecting ecosys te $m$ responses to anthropoge nic stress. Canadian Journal of Fisheries and Aquatic Sciences. 44(Suppl. 1):6-25.

Shannon, C.E. and Wiener, W. (1949) The mathematical theory of communication. University of Illinois Press Urbana, $125 \mathrm{pp}$.

Simpson, E. H. (1949) Measurement of diversity. Nature pp163- 688.

Singh R.K. (1986) Fluctuations in the composition of zooplankton population in relation to hydrobiological conditions of a reservoir. J. Hydrobiol., 2(3): 37-42.

Trivedy, R.K. and Goel, P.K. (1986) Chemical and biological methods for water pollution studies, Environmental Publication, Karad Maharastra, India. pp. 247.

Umavathi, S., Longakumar, K and Subhashini. (2007) Studies on the nutrient content of Sulur pond in Coimbator, Tamil Nadu, Journal of ecology and environmental conservation, 13(5), pp 501-504.

Victor, R. and Fernando, C.H. (1979) The fresh water ostracopoda (Crustacea: ostracoda) of India. Records of the zoological survey of India.74 (2) 147-242.

Ward, H.B. and Whipple, G.C. (1959) "Fresh-Water Biology," $2^{\text {nd }}$ Edition, John Wiley, New York.

World Health Organization, (2004) Guidelines for Drinking-water Quality.Vol.1: $3^{\text {rd }}$ d. Geneva. 